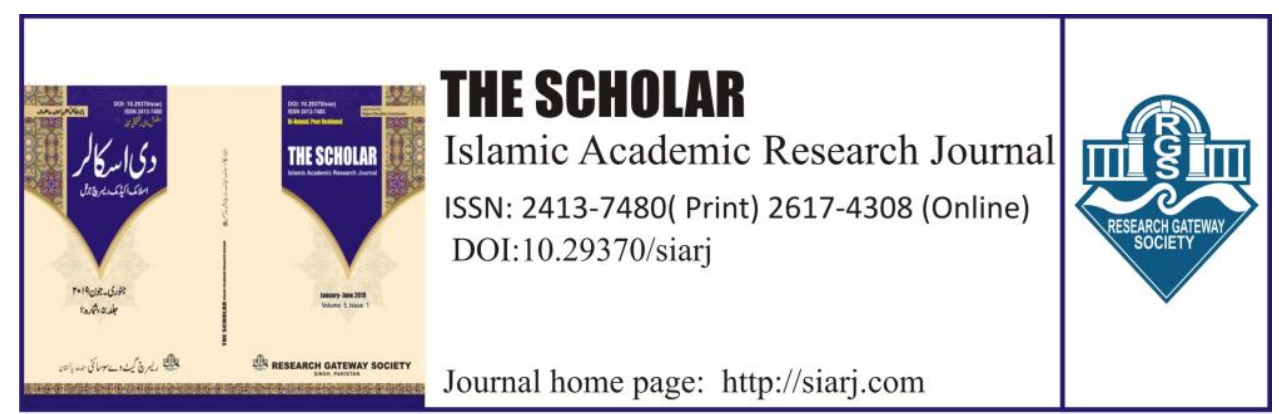

\title{
SUPREMACY OF HUMANITY IN THE LIGHT OF SEERAT-UN-NABI (PBUH)
}

\section{Muhammad Ayaz}

Ph.D. Scholar, Department of Islamic Studies,

The Islamia University of Bahawalpur,

Pakistan.

Email : ayaz.te.bwp@gmail.com

ORCID ID:

https://orcid.org/0000-0002-3250-4559
2. Hafiz Iftikhar Ahmad

Associate Professor, Chairman Department

of Islamic Studies, The Islamia University of

Bahawalpur, Pakistan.

Email:iftikhar.ahmad@iub.edu.pk

ORCID ID:

https://orcid.org/0000-0003-3115-6000

To cite this article:

Ayaz, Muhammad, and Hafiz Iftikhar Ahmad. "ENGLISH-SUPREMACY OF

HUMANITY IN THE LIGHT OF SEERAT-UN-NABI (PBUH)." The Scholar-Islamic Academic Research Journal 5, No. 1 (January 10, 2019): 1-20.

To link to this article: https://doi.org/10.29370/siarj/issue8ar8

\begin{tabular}{|c|c|}
\hline Journal & $\begin{array}{l}\text { The Scholar Islamic Academic Research Journal } \\
\text { Vol. 5, No. } 1 \text { || January -June } 2019 \text { || P. 1-20 } \\
\text { Research Gateway Society }\end{array}$ \\
\hline DOI: & $10.29370 /$ siari/issue 8 ar8 \\
\hline URL: & https://doi.org/10.29370/siari/issue8ar8 \\
\hline License: & Copyright c 2017 NC-SA 4.0 \\
\hline Journal homepage & www.siarj.com \\
\hline Published online: & 2019-1-11 \\
\hline
\end{tabular}
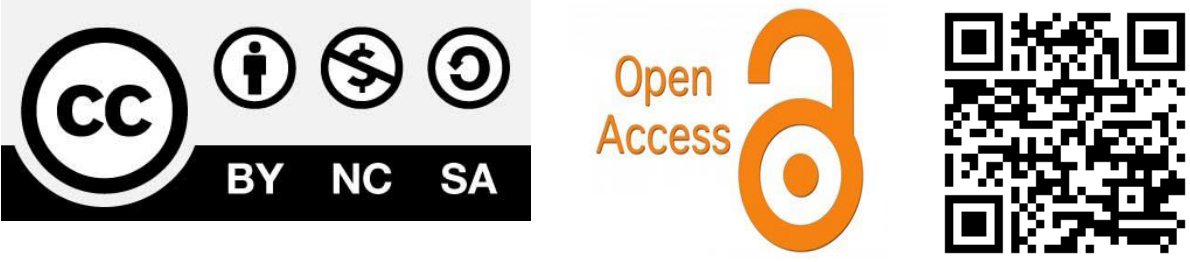
THE SCHOLAR (January - June 2019)

\title{
SUPREMACY OF HUMANITY IN THE LIGHT OF SEERAT-UN-NABI (PBUH)
}

\author{
Muhammad Ayaz, Hafiz Iftikhar Ahmad
}

\begin{abstract}
A message of Seerat-un-Nabi is supremacy of humanity. The Holy Prophet (PBUH) verbally as well as practically ensured to respect mankind. Supremacy of humanity means that a man didn't cross the etiquettes in case of having appositive views as well as in war.It would be the respect of mankind that if he gives him respect without a chill as regarded him a man and treated him on the grounds of self-esteem as well as do cooperation with him. The Prophet Muhammad (PBUH) has given orders to respect a man on the humanitarianism. He ensured to deal with respect of life under moral bondages. In a broader sense that no one will put views against the respect of mankind but practically many things will create the hurdles in this way. On those expectations which have been chosen and taught by the Prophet of Allah to give respect to mankind are the key elements towards the supremacy of humanity. The savior of mankind Prophet Muhammad (PBUH) has given the basic steps which create the respect for mankind, in which prominent things are as follows.
\end{abstract}

KEYWORDS: Supremacy, Conspirator, Aversion, Humanity, Impeded

\section{INTRODUCTION:}

Usually a man respect to others with the thought that my friends and knowing person are able to give them respect while his foe are not able to 
give them respect. In dealing with others foes he ruined the human values. This is not as per the Șūnnāt Nābwi. It is vivid from the sacred Seerat Nabi (PBUH) that he showed moral values without discrimination. He gives respect to mankind without aversion and non-aversion. Yahood are severe enemies of Islam. They always give loss to Islam and the Prophet Muhammad (PBUH) on each step with new ways through conspirator mentality.

It is said in sacred Quran regarding their animosity against Islam:

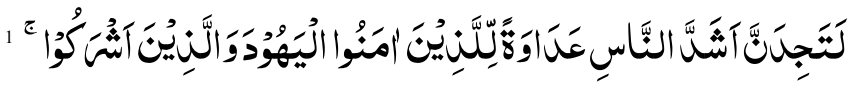

"And you will certainly find that the people most hostile against the believers are the Jews and the ones who ascribe partners to Allah.”

It has been explored in verse that Yahood, Jews and those who were worshiping someone other than Allah were bitter enemies of Islam. But among them Jews were on top priority. Before and after migration to Madina their conspiracies were not hidden. Inspite of these deviations and aversions the following incident reflecting from Seerat Nabi (PBUH) that how to behaved with Jews on the grounds of mankind. Narrated 'Abdur Rahman bin Abi Laila (RA) that:

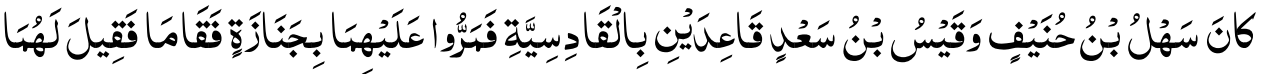

\footnotetext{
${ }^{1}$ Al-Quran, v. 5:82.
} 


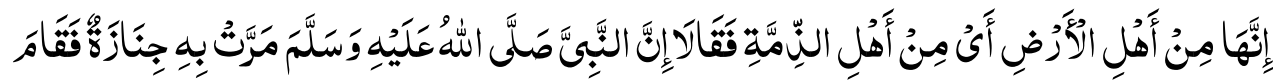

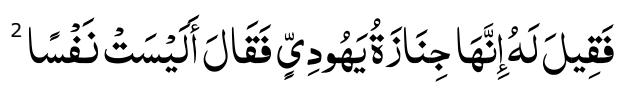

Sahl bin Hunaif and Qais bin Sad were sitting in the city of AlQadisiya. A funeral procession passed in front of them and they stood up. They were told that funeral procession was of one of the inhabitants of the land i.e. of a non-believer, under the protection of Muslims. They said, "A funeral procession passed in front of the Prophet Muhammad (PBUH) and he stood up. When he was told that it was the coffin of a Jew, he said, "Is it not a living being (soul)?"

It has been explored in this way that what are the demands to respect mankind and how to fulfill them. Even in state of war he has forbidden to kill a man who is not taking a part in war. It was narrated that Hanzalah Al-Katib said:

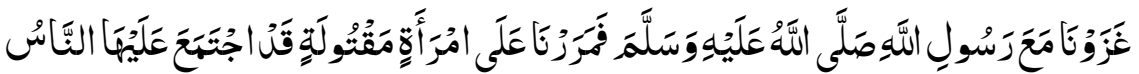

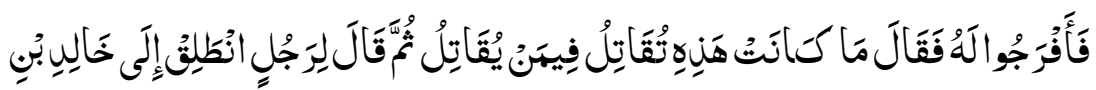

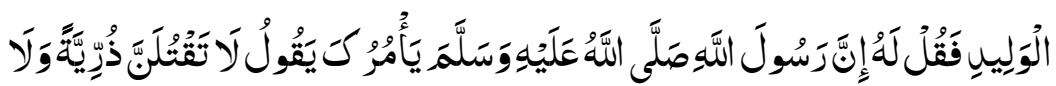

\footnotetext{
${ }^{2}$ Abu Abdullah Al-Bukhari, Sahih Al-Bukhari, vols. 2, Hadith 1312, Pg. 85.
} 
"We went out to fight alongside the Messenger of Allah (PBUH) and we passed by a slain woman whom the people had gathered around. They parted (to let the Prophet (PBUH) through) and he said: 'This (woman) was not one of those who were fighting.' Then he said to a man: 'Go to Khalid bin Walid and tell him that the Messenger of Allah (PBUH) Commands you: "Do not ill any Women or any (farm) aborer."'

It has been explored that the circle of respect of mankind is not limited with nears and dears, it has been expand with foes in-spite of all aversions and human values will be dominant. When you reat at the state of killing then you may not cross the human values. He has forbid the killing of his enemy along with steps after giving various punishments. Abu Ayyub al-Ansari (RA) said that:

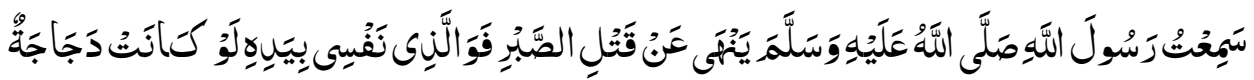

"I heard the Apostle of Allah (PBUH) prohibiting to kill in confinement. By Him in Whose hands my soul is, if there were a hen, I would not kill it in confinement."

In the age of ignorance people do the corpses into pieces. It means

\footnotetext{
${ }^{3}$ Ibn Majah al-Qazvini, Sunan Ibn Majah, vols. 2, Hadith 2842, Pg. 948.

${ }^{4}$ Abu Dawud as-Sijistani, Sunan Abi Dawud, vols. 3, Hadith 2687, Pg. 60.
} 
they separate their parts of body after killing their enemies. In the battle of Uhad the corpse of Hazrat Ameer Hamza (RA) was do in pieces. It is against the respect of humanity, it is therefore forbidden by Hazrat Muhammad (PBUH) of this act. Narrated by Abdullah bin Yazid Al Ansari (RA) that:

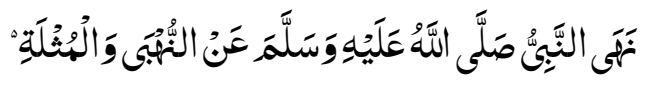

"The Prophet (PBUH) forbade robbery (taking away what belongs to others without their permission), and also forbade mutilation (or maiming) of bodies."

Therefore $\mathrm{He}$ forbade to ascension to someone. It has been clarified that respect of mankind is first step. To give respect a man on human grounds and do not ruined the human values in the state of war.

\subsection{NEGATE THE DILEMMA OF HUMAN CATEGORIZE}

One another thing which has been disgraced a large number of mankind was the categorization of humanity. That was the division of mankind. Regard has been given to a specific category. That division was exit in some way in whole the world. Masters and servants in Arab, Kurd in Iraq, Barhaman, khashtari Vaish and Shodar in India and etc are the examples. In somewhere this was categorized in shape of religion that rules will be different for a common man and other rules will be framed for a priest other than common man. Somewhere it has been categorized in Arabic and Persian and somewhere are white and black. In this way respect of

\footnotetext{
${ }^{5}$ Abu Abdullah Al-Bukhari, Sahih Al-Bukhari, vols. 3, Hadith 2474, Pg. 135.
} 
mankind has been broken into pieces.

At that time when mankind was categorized in different races then the Prophet Muhammad (PBUH) raised his voice for the unity of mankind. He (PBUH) bestowed with respect to the inferior category of humanity. Hazrat Muhammad (PBUH) said that:

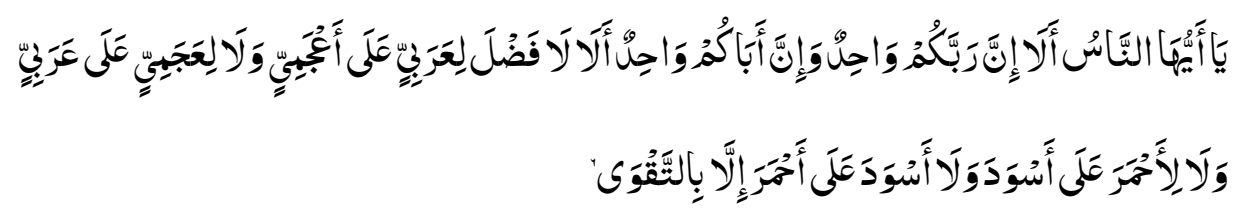

"Your God is one and your father is one. There is no dominancy of Arabic on Persian and Persian on Arabic. No red on blacks and no black on reds. There is only one thing which is poise."

It has been clarified from this point of Seerat-un-Nabi (PBUH) that supremacy and superiority is not lineal and not an argument to born in a family is the reason of inferiority. If a man has been born in a family which is inferior in eyes of people and what is the fault of born baby? Has he had considered accused without doing a crime? If he had not done any sin then why punishment is given to him. Prophet Muhammad (PBUH) has explained the way of superiority and who will follow that way, he will find dignity and respect. It has been bestowed by Allah to humanity that born him a respectable.

A man who will sustain this credit will be respectable without any discrimination of color, creed and division of continents.

\footnotetext{
${ }^{6}$ Bayhaqi Abu Bakkar, Shuab-Ul-Iman, vols. 7, Hadith 4774, Pg. 132.
} 
Supremacy of humanity in the light of Seerat-un-Nabi (pbuh)

A man who will not sustain it will lose this status. Self-made categorization has divided the mankind and dropped him from sight. Prophet Muhammad (PBUH) has worn the crown of respect and blessings to that category. He (PBUH) do wedlock of his servant Hazrat Zaid (RA) with his material cousin Hazrat Zainab (RA) and proved practically and also finish the difference of masters and servant.

On the event of victory of Makkah Prophet Muhammad (PBUH) said to Hazrat Bilal (RA) to go upward on the roof of Kaaba and say Azzan. It was great honor which was given by Prophet Muhammad (PBUH) to the servants. By following the instruction of Prophet Muhammad (PBUH) Hazrat Bilal (RA) went upward on the roof of Kaaba and said Azaan. At that time Banu Quraish has felt bad that respect has been given to a servant. After seeing this scene they mourned. One of them Attab said that thanks Allah my father had been died before this scene. Haris bin Hashaam said that in-spite of this blackish crow no one has present to say Azzan. Sahhal Bin Ammar said with grief "As the will of Allah". At that time this verse has been revealed.
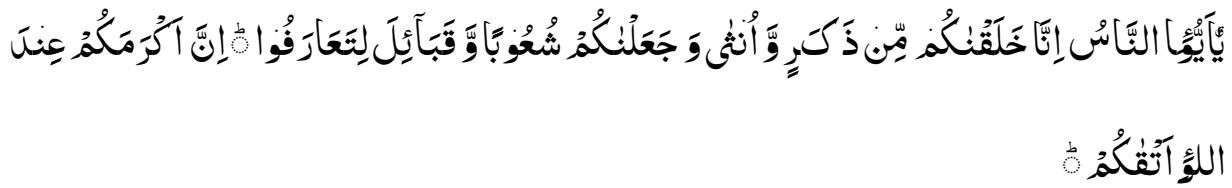

"O mankind, We have created you from a male and a female and made you into races and tribes, so that you may identify each other. Surely the noblest of you, in Allah's sight, is the one who is most pious of you."

It means that families and tribes are just for introduction. These are 
not for inferiority and superiority.

Narrated by Sayyidina Abu Hurayrah (RA) that Prophet Muhammad (PBUH) said:

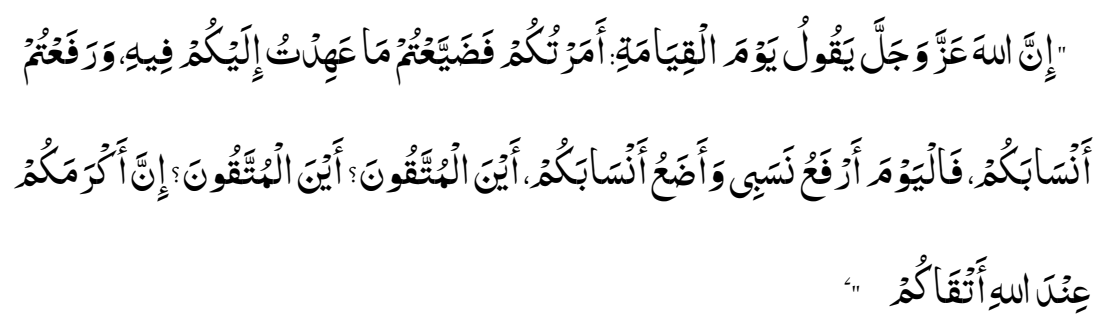

"On the day of judgment Allah will say that I have given you order but you have not follow my order. You have raised your races. Today I shall raise my race and waste your all races. Where are poise and God-fearing? Where are poise and God-fearing? In before of Allah a man is respectable who is poise and Godfearing."

Prophet Muhammad (PBUH) has removed the difference in races and colors and also gives awareness on the respect of mankind. He has opened the way of superiority on the basis of equality and worn the crown of respect for those people who was considered inferior.

\subsection{SAFETY OF HONOR AND PRESTIGE}

The demands of given respect to mankind which have been explained by the Prophet Muhammad (PBUH), in which honor and prestige are important. If a man do not safe the honor and prestige of

\footnotetext{
${ }^{7}$ Bayhaqi Abu Bakkar, Shuab-Ul-Iman, vols. 7, Hadith 4775, Pg. 132.
} 
another man then he is unaware the respect of mankind. If someone is young or old, rich or poor, kind or beggar than each of them has a respect whose protection is the dignity of humanity. Creating insult for someone or dishonoring someone is the result of considering a man inferior. Prophet Muhammad (PBUH) has eradicated those roots that created hurdles in giving respect to mankind. Narrated by Abdullah bin Mas'ud (RA) that Prophet Muhammad (PBUH) said:

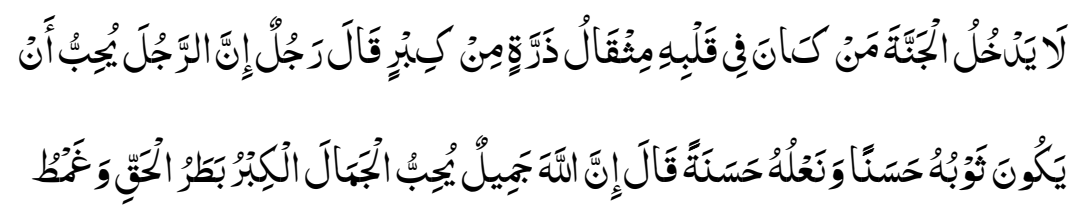

"He who has in his heart the weight of a mustard seed of pride shall not enter Paradise. A person (amongst his hearers) said: Verily a person loves that his dress should be fine, and his shoes should be fine. He (the Holy Prophet) remarked: Verily, Allah is Graceful and He loves Grace. Pride is disdaining the truth (out of self-conceit) and contempt for the people."

Clothes have best, to ride in a coach and residence will be good. These things are not pride. Allah likes these things. Proudness is that a man knows right way and make an ego and considered to others inferior. A man who considered inferior to others will not safe the honor and prestige of others. Prophet Muhammad (PBUH) said that it is a major sin of usury those who attacks on the respect of a man. Narrated by Sa'id ibn

\footnotetext{
${ }^{8}$ Alnisaborri, Al-Musnadu Al-Sahi Al-Mukhtasir Bi Naklil Adli Unil Adli Illa Rasool Allah Sallallahu Alaihi Wasallim (Sahi Muslim), vols. 1, Hadith 147, Pg. 93.
} 
Zayd that Prophet (PBUH) said that:

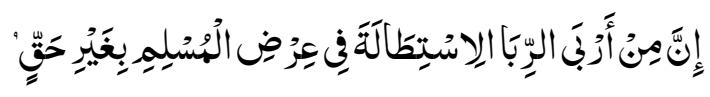

"The most prevalent kind of usury is going to lengths in talking unjustly against a Muslim's honor."

No doubt usury sin is so major that a man attack on the respect of his brother. Prophet Muhammad (PBUH) has disapproved each and everything that ruined the respect of humanity.

Therefore $\mathrm{He}(\mathrm{PBUH})$ has forbid from back biting, suspense and nagging to someone and describing the respect of humanity. Sayyidina Amr ibn Ahwas reported that he heard Allah's Messenger (PBUH) say to the people on the day of the last sermon:

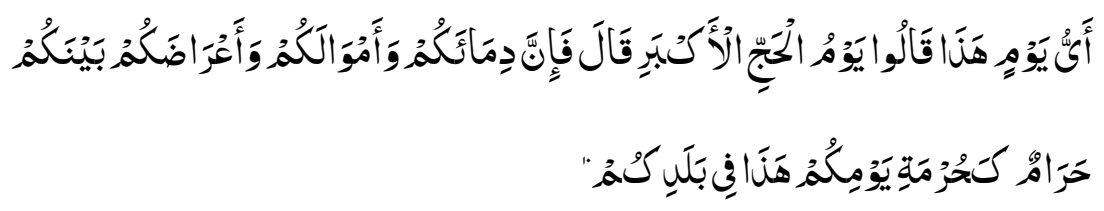

"What day is it today?" They said, "The day of the great pilgrimage." He said, "So, indeed your blood your properties and your honor are sacred to each other of you as the sanctity of this your day in this your city."

It has been explored from the message of Prophet Muhammad (PBUH) that as a Muslim respect to Kaaba, should do respect to other people. Sayyidina Abu Hurayrah (RA) reported that Allah's Messenger (PBUH) said:

\footnotetext{
${ }^{9}$ Abu Dawud as-Sijistani, Sunan Abi Dawud, vols. 4, Hadith 4876, Pg. 269.

${ }^{10}$ Al-Tirmidh, Al-Jami Al-Kabir (Sunan Al-Tirmidhi), vols. 4, Hadith 2159, Pg. 31.
} 


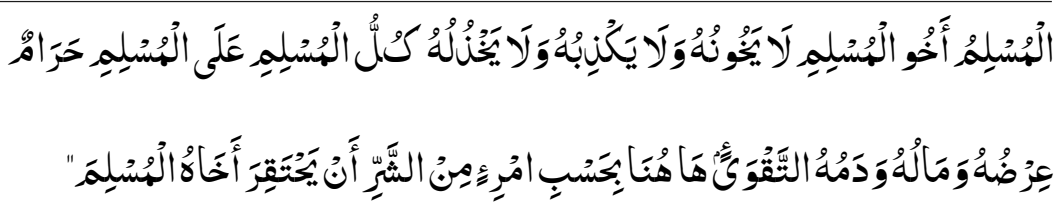

"A Muslim is the brother of a Muslim. So, he must not betray him, tell him lies or adandon him. Everything of a Muslim that is unlawful to another Muslim includes his honor, his property and his blood. Taqwa (تقوى) is here (in the heart). It is enough to know a man is evil when he belittles his brother."

When a thing has been told in aspect of disgrace then the Prophet Muhammad (PBUH) restored his grace with wisdom and restrained to others. Sayyidina Anas (RA) reported that:

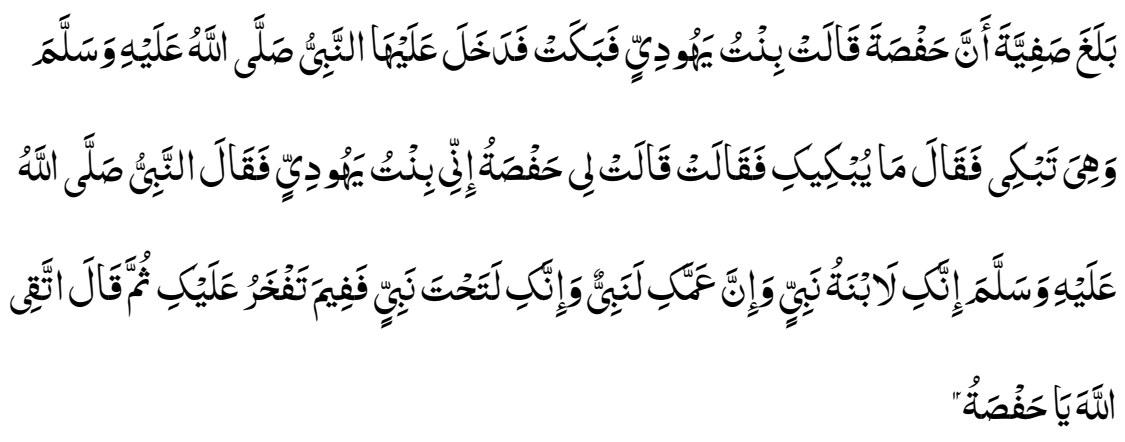

Sayyidah Safiyah (RA) had learnt that Sayyidah Hafsah commented (about her), 'Daughter of a Jew.' So, she wept, The Prophet (PBUH) went to her and found her weeping. He asked her, 'Why do you weep?" She said, "Hafsah says to me that lam the daughter of a Jew." The Prophet (PBUH) said, "And you are the daughter of a Prophet (PBUH) and your uncle was a Prophet

\footnotetext{
${ }^{11}$ Al-Tirmidh, vols. 3, Hadith 1927, Pg. 389.

${ }^{12}$ Al-Tirmidh, vols. 6, Hadith 3894, Pg. 192.
} 
The Scholar Islamic Academic Research Journal

Vol. 5, No. 1 || January -June 2019 || P. 1-20

https://doi.org/10.29370/siarj/issue8ar8

(PBUH) and you are in marriage with a Prophet. So, of what does she boast over you?" Then he said, "Fear Allah, O Hafsah!"

As this statement was not as per the status of Hazrat Safia (RA) therefore beloved Prophet Muhammad (PBUH) encouraged her and warned to Hazrat Hafsa (RA). Narrated by Aisha (RA), Ummul Mu'minin (RA) that:

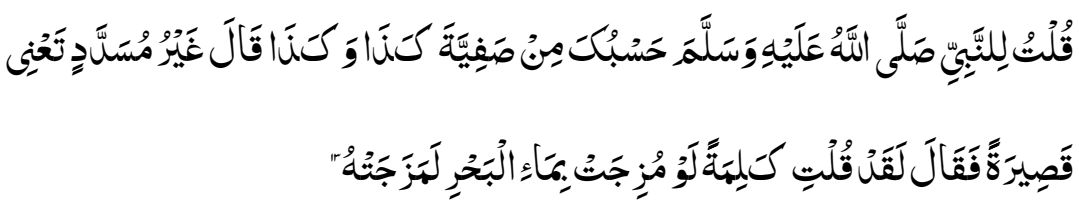

"I said to the Prophet (PBUH) it is enough for you in Safiyyah that she is such and such meaning that she was short-statured (It was indication to her height). He replied; you have said a word which would change the sea if it were mixed in it."

Hazrat Urwa (RA) said that on the occasion of Hajj beloved Prophet Muhammad (PBUH) has departure late from Arafat due to Usama Bin Zaid (RA). Urwa (RA) said:
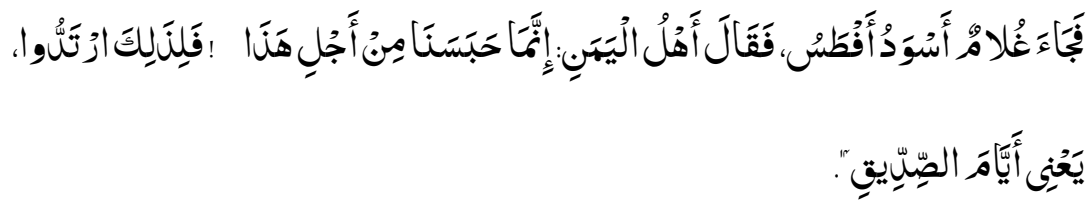

"Then a boy came his color was black and his nose was short (pug). Then the resident of Yamman said we have stopped for that boy. He (Hazrat Urwa (RA)) said that due to this reason they have opposed Islam in the reign of Hazrat Abu Bakkar (RA)."

From this aspect of Seerat-un-Nabi (PBUH) it has been cleared that

\footnotetext{
${ }^{13}$ Abu Dawud as-Sijistani, Sunan Abi Dawud, vols. 4, Hadith 4875, Pg. 269.

${ }^{14}$ Al-Zahbi, Tareekh Al-Islam Wawafiyat Al-Mushahir Wal Ailaam, vols. 4, Pg. 177.
} 
The Scholar Islamic Academic Research Journal

Vol. 5, No. 1 || January -June 2019 || P. 1-20

https://doi.org/10.29370/siarj/issue8ar8

one aspect of respect of mankind is to create safety and prestige of mankind.

\subsection{RESPECT OF RELIGIOUS FEELINGS}

It does not mean of respect of mankind that a man respects to other man but affront to his father. It is clear without any doubt that he does respect each and everything which he considered respectable. It is also fact that religion of a man is dear to him in comparison of other man as well as his religion. It seems impossible that do respect without caring his religion. On which ground beloved Prophet Muhammad (PBUH) has established the basis that a person must do respect to other religions. He Prophet Muhammad (PBUH) told us the order of Allah:

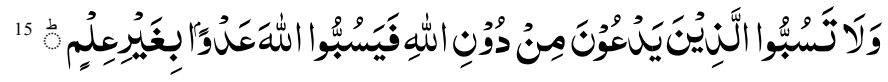

"And do not abuse (Insult using foul language) those whom they invoke other than Allah, lest they should abuse Allah trangressingly without knowledge."

It has been said regarding respect to the worshiping places of non-

Muslims.

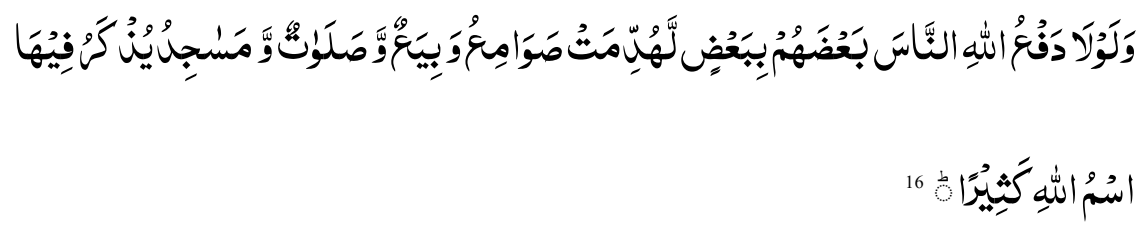

"And if Allah had not removed men one by means of other, then

\footnotetext{
${ }^{15}$ Al-Quran, v. 6:108.
}

${ }^{16}$ Al-Quran, v. 22:40. 
The Scholar Islamic Academic Research Journal

Vol. 5, No. 1 || January -June 2019 || P. 1-20

https://doi.org/10.29370/siarj/issue8ar8

necessarily, the cloisters and churches and synagogues and mosques wherein the name of Allah is mentioned much would have been pulled down."

To respect own worship place is an emotional as well as natural. There Churches and other worshipping places have been given dominancy with the reason that the religion has been bestowed to beloved Prophet Muhammad (PBUH), in which respect of these places is not less than Mosques.

Beloved Prophet Muhammad (PBUH) has always do respect of other religious feelings because it is the aspect of respect to mankind. When the delegation of Najran has come to the Prophet Muhammad (PBUH) on $9^{\text {th }}$ Hijri then the said delegation met in Masjid Nabvi. When the time came for worship then Prophet Muhammad (PBUH) allowed them to worship in Masjid Nabvi. Ibn Kathir Said:

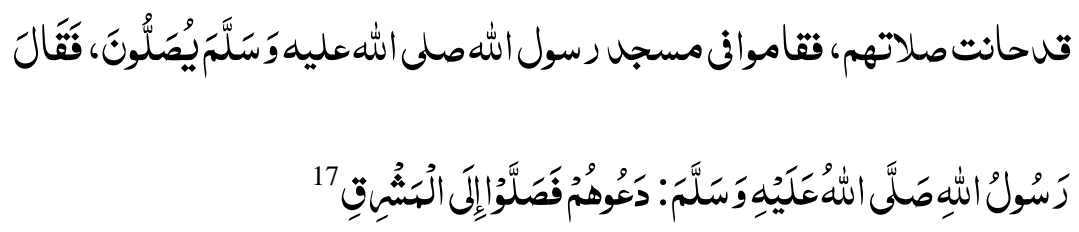

"When the worship time came they worshiped in Masjid Nabwi.

He said no one cannot do objection. They offer their prayer on the side of East."

It is mentionable that music was included in their worship. It has been guessed easily that how Prophet Muhammad (PBUH) deals to the religious

\footnotetext{
${ }^{17}$ Fateh Ud Deen, Oyon UI Asar Fi Fanoon UI Magazee WashSamail Wasair, vols. 1, Pg. 253.
} 
The Scholar Islamic Academic Research Journal

Vol. 5, No. 1 || January -June 2019 || P. 1-20

https://doi.org/10.29370/siarj/issue8ar8

feelings and beliefs of Non-Muslims. When the Prophet Muhammad (PBUH) came in Madina and did the agreement with Jews which is called constitution of Madina. In which one thing was that:

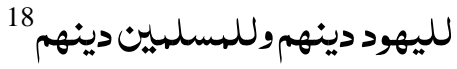

"Jews will follow their religion and the Muslims will follow their religion."

Its mean both of them will not interfere in others religious worships. It was the result of the preaching of Prophet Muhammad (PBUH) that the Muslims have respect to the religious activities of others. After the victory of Palestine Hazrat Umer Farooq (RA) has given the constitution to residents, which are mentioned here:

"This is the agreement of peace which has been given by the worshiper of Allah name Umer to the residents of Alia. Safety of their life, money and Churches will be ensured. Every citizen, whether he is healthy or ill is in our safe custody. Their churches will not change in homes, nor they will be demolished, their properties and Crosses will not be harmed, nor any religious pressure will put on them and nor anyone be disturbed." When a man do respect to other man then he respect each and everything which is respectable. It is clear that respect may be made to religion because religion is precious and beloved for everyone. Religion is

\footnotetext{
${ }^{18}$ Hisham, Seerat Ibn Hisham, vol. 2. Pg. 144.
} 
The Scholar Islamic Academic Research Journal

Vol. 5, No. 1 || January -June 2019 || P. 1-20

https://doi.org/10.29370/siarj/issue8ar8

important and a man has grip on his religion and he may be able to give argument to prove his religion. In lenient way he may explain the others false religion. It is not against the humanity, although taunting is not allowed. Beloved Prophet Muhammad (PBUH) has always given the message of respect of mankind because it is the demand of supremacy of humanity.

\subsection{PROHIBITION OF KILLING OF INNOCENT}

When the Prophet Muhammad (PBUH) raised his voice regarding supremacy of humanity, at that time the respect of mankind has been ruined. On valueless issues fighting has been initiated, many persons have also be killed and without discrimination a number of corpses have been gathered there. The fire of revenge has expanded and they killed each other without caring the mankind.

Prophet Muhammad (PBUH) has explained the respect of a man and say it a major sin if a man killed blameless. Without fact he has forbidden to kill a man. It is also said in Quran:

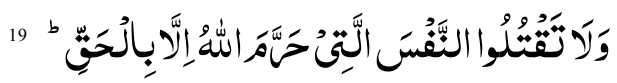

"And do not kill the soul which Allah has forbidden [to be killed] except by [legal] right."

\footnotetext{
${ }^{19}$ Al-Quran, v. 6:151.
} 
The Scholar Islamic Academic Research Journal

Vol. 5, No. 1 || January -June 2019 || P. 1-20

https://doi.org/10.29370/siarj/issue8ar8

Respect of human's life is necessary but human life is not loving before truth. If truth demands the killing of humanity then truth will be given dominancy. Here a Hadith have been mentioned regarding explaining the truth which is narrated by Adullah (RA) that Prophet Muhammad (PBUH) said:

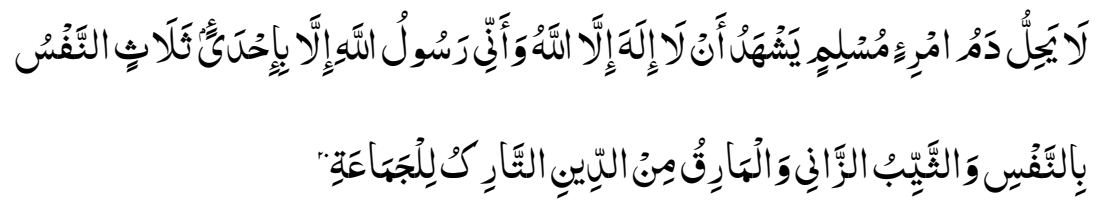

"The blood of a Muslim who confesses that none has the right to be worshipped but Allah and that I am His Apostle, cannot be shed except in three cases: In Qisas for murder, a married person who commits illegal sexual intercourse and the one who reverts from Islam (apostate) and leaves the Muslims."

It is vivid in above explanation that killing is not allowed in-spite of above reasons. In-spite of all other aversions Muslims has not a right to kill a man. It is also clear that implementation of punishment is only allowed to state or Government. Personally it is not allowed. To respect of blood is the demand of respect of mankind. Prophet Muhammad (PBUH) has strictly forbidden the killing of humanity. Hazrat Ibna Abbas said that a man has been killed in Madina in the period of Nābūwāṭ. The accused has not been recognized. Prophet Muhammad (PBUH) came to the people and said:

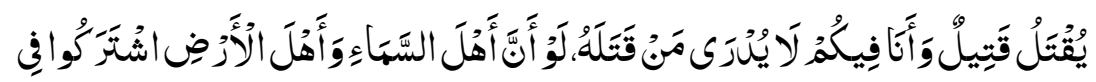

\footnotetext{
${ }^{20}$ Abu Abdullah Al-Bukhari, Sahih Al-Bukhari, vols. 9, Hadith 6878, Pg. 5.
} 
"A man has been killed and I am present among you and I didn't know who kill him. If all the creations of earth and sky gather to kill a man, Allah will give torment to all but He will do as He will do like." Prophet Muhammad (PBUH) has strictly forbidden killing a man, now a concept came in the minds that assistance in killing will take beyond a man from the blessing of Allah. It is narrated from Abu Hurairah (RA) that the Messenger of Allah (PBUH) said:

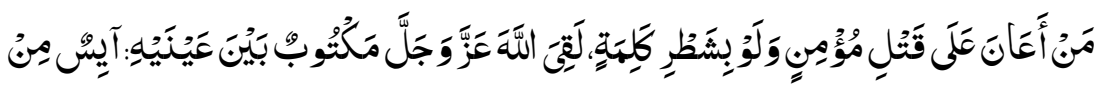

$$
\text { رَحْمَةِ النَّكِد" }
$$

"Whoever helps to kill a believer, even with half a word, he will meet Allah with (the words) written between his eyes, 'He has no hope of the mercy of Allah'"

Prophet Muhammad (PBUH) has always prohibited killing an innocent. Even in war beyond the war rules of Arabs and in reference of killing $\mathrm{He}(\mathrm{PBUH})$ always impeded strictly. $\mathrm{He}(\mathrm{PBUH})$ impeded to killing children, women and old men. He (PBUH) regarded that the life of Momin (مومن) is more sacred then Kaaba. It is narrated from Bara' bin 'Aazib that the Messenger of Allah (PBUH) said:

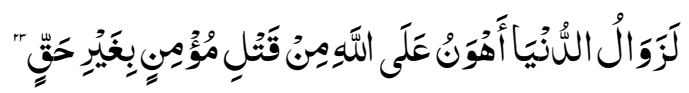

"If this world were to be destroyed, that would be less significant

\footnotetext{
${ }^{21}$ Bayhaqi Abu Bakkar, Al-Sunnan Al-Kubra Lilbayhaqi, vol. 8, vols. 8, Hadith 15864, Pg. 41.

${ }^{22}$ Ibn Majah al-Qazvini, Sunan Ibn Majah, vols. 2, Hadith 2620, Pg. 874.

${ }^{23}$ Ibn Majah al-Qazvini, vols. 2, Hadith 2619, Pg. 874.
} 
The Scholar Islamic Academic Research Journal

Vol. 5, No. 1 || January -June 2019 || P. 1-20

https://doi.org/10.29370/siarj/issue8ar8

before Allah than the unlawful killing of a believer."

It does not mean that the blood of non-Muslims is not sacred, it has been told as per relevancy of the situation. Prophet Muhammad (PBUH) has given the lesson to respect of life of each person without any discrimination of Muslim or Non-Muslim.

In respect the life of unbelievers the Prophet Muhammad (PBUH) said:

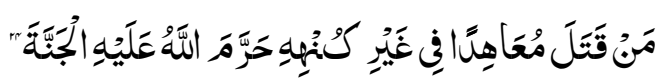

"The Prophet (PBUH) said if anyone kills a man whom he grants protection prematurely, Allah will forbid him to enter Paradise."

It is further stated that who have killed a living will not snuff the fragrance of paradise and that will be snuff from the distance of forty years. Prophet Muhammad (PBUH) said that:

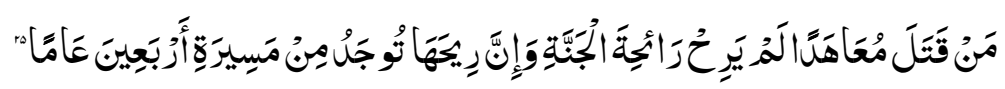

"Whoever killed a person having a treaty with the Muslims, shall not smell the smell of Paradise though its smell is perceived from a distance of forty years."

\subsection{CONCLUSION}

The summary is that an important message of Seerat-un-Nabi is human dignity, and it means that human beings should be regarded as being human only. His honor, religion and wealth should also be

\footnotetext{
${ }^{24}$ Abu Dawud as-Sijistani, Sunan Abi Dawud, vols. 3, Hadith 2760, Pg. 83.

${ }^{25}$ Abu Abdullah Al-Bukhari, Sahih Al-Bukhari, vols. 4, Hadith 3166, Pg. 99.
} 
The Scholar Islamic Academic Research Journal

Vol. 5, No. 1 || January -June 2019 || P. 1-20

https://doi.org/10.29370/siarj/issue8ar8

respectable. And a person must be honored as a human being as he wants for himself. It will promote peace in society and the nation will be on the path of development. As Muslim by following this aspect of supreme humanity we have to convey the message to all mankind that the narrative of the Prophet Muhammad (PBUH), which clearly describes the supreme humanity, has the welfare of all religions and in its light people can climb the stairs of success and happiness, and in the light of this the world can become a peacekeeping destination.

\section{(ब)()}

This work is licensed under a Creative Commons

Attribution-NonCommercial-ShareAlike 4.0 International (CC BY-NC-SA 4.0) 